University of Nebraska - Lincoln

DigitalCommons@University of Nebraska - Lincoln

U.S. Navy Research

U.S. Department of Defense

Winter 2005

\title{
Perchlorate: Sources, Uses, and Occurrences in the Environment
}

Clayton W. Trumpolt

Colorado Department of Public Health and Environment

Michael Crain

Hazardous, Toxic, and Radioactive Waste Center of Expertise

Geoffrey D. Cullison

Environmental Readiness Division of the Office of Chief of Naval Operations,

geoffrey.cullison@navy.mi1.ira

Susan J. P. Flanagan

Institute of Makers of Explosives

Lenny Siegel

Center for Public Environmental Oversight

See next page for additional authors

Follow this and additional works at: https://digitalcommons.unl.edu/usnavyresearch

Part of the Operations Research, Systems Engineering and Industrial Engineering Commons

Trumpolt, Clayton W.; Crain, Michael; Cullison, Geoffrey D.; Flanagan, Susan J. P.; Siegel, Lenny; and Lathrop, Stephen, "Perchlorate: Sources, Uses, and Occurrences in the Environment" (2005). U.S. Navy Research. 25.

https://digitalcommons.unl.edu/usnavyresearch/25

This Article is brought to you for free and open access by the U.S. Department of Defense at DigitalCommons@University of Nebraska - Lincoln. It has been accepted for inclusion in U.S. Navy Research by an authorized administrator of DigitalCommons@University of Nebraska - Lincoln. 
Authors

Clayton W. Trumpolt, Michael Crain, Geoffrey D. Cullison, Susan J. P. Flanagan, Lenny Siegel, and Stephen Lathrop

This article is available at DigitalCommons@University of Nebraska - Lincoln: https://digitalcommons.unl.edu/ usnavyresearch/25 


\section{Perchlorate: Sources, Uses, and Occurrences in the Environment}

Clayton W. Trumpolt

Michael Crain

Geoffrey D. Cullison

Susan J. P. Flanagan

Lenny Siegel

Stephen Lathrop
Perchlorate contamination of groundwater and soil continues to be a hot topic in many sectors, including industry, the federal Departments of Defense and Energy, regulators, and the general public. This article presents information on what is currently known regarding perchlorate uses, known and suspected naturally occurring versus anthropogenic perchlorate sources, and past and present manufacturing locations. It provides the reader with a baseline as well as background information to facilitate an understanding of perchlorate in the environment for the ultimate purpose of remediation. The article is based on research conducted by the Interstate Technology Regulatory Council for a forthcoming, more substantial perchlorate overview document scheduled for publication later in 2005. The document will include an overview of the chemical and discussions of remediation techniques and methods of analysis. (c) 2005 Wiley Periodicals, Inc.

\section{INTRODUCTION}

Perchlorate $\left(\mathrm{ClO}_{4}^{-}\right)$has become an ever more visible concern since the detection limit was reduced from $400 \mu \mathrm{g} / \mathrm{L}$ to approximately $1 \mu \mathrm{g} / \mathrm{L}$ in the late $1990 \mathrm{~s}$ due to improved analytical methodology. Concurrently, the knowledge base regarding the uses, distribution in the environment, and origins of perchlorate contamination has expanded as the ability to detect perchlorate's presence has increased. The goal of this article is to present background information on perchlorate that until relatively recently existed only in somewhat obscure research papers, little known and less widely circulated references, and new information gathered as a result of the increased focus on this chemical. The information contained herein will prove useful to those investigating perchlorate in the environment with the goal of remediating contamination, as well as those entities tasked with environmental regulation.

\section{SOURCES, USES, AND OCCURRENCES OF PERCHLORATE}

Perchlorate occurs both naturally and as a manufactured compound. Knowing the sources of perchlorate and the variety of uses it has served will help to guide perchlorate investigations as well as remediation. While a variety of sites where perchlorate contamination is known to occur have already been identified, it can be assumed that further sites will be discovered as more geographical areas are tested and additional information becomes available. 
In contrast, man-made perchlorate sources can be many times more concentrated than most natural sources.

\section{Sources of Perchlorate}

At this time, most naturally occurring sources of perchlorate appear to be geographically limited to arid environments. These deposits tend to be of low concentration, except for the relatively high natural perchlorate concentrations found in Chilean caliche (precipitated salts in soil from evaporated wetting fronts) and some potash ores. In contrast, man-made perchlorate sources can be many times more concentrated than most natural sources. In environments where both types exist, research to discriminate between the two types is ongoing.

Sites that have been identified with high concentrations of perchlorate contamination (in the thousands of ppb or more) involve manufacturing, testing, or disposal of solid rocket propellant; manufacturing of perchlorate compounds; and industrial manufacturing operations where perchlorate compounds were used as reagents. In addition to covering these kinds of sources of contamination, this section will also address potential sources of man-made perchlorate that are likely to have created lower concentrations of perchlorate contamination. In these cases, it is assumed that the quantities of perchlorate causing the contamination are smaller or the sources are disseminated.

\section{Natural Sources of Perchlorate}

\section{Theory of the Origin of Natural Sources of Perchlorate}

A current theory regarding the origin of naturally occurring perchlorate in the environment centers on natural atmospheric processes. While the exact mechanism for the creation of perchlorate is unknown, the theory suggests that chloride, possibly in the form of sodium chloride from the sea or land-based chloride compounds blown in from the atmosphere, reacts with atmospheric ozone. In the atmosphere, photochemical reactions between chloride and ozone create perchlorate. This process probably occurs over much of the earth and is analogous to nitrate formation in the atmosphere (Walvoord et al., 2003). In addition, there is the possibility that lightning may play a role in the creation of some atmospherically produced perchlorate (Dasgupta et al., 2005; W. A. Jackson et al., 2003), but this theory has not been confirmed. The rate of perchlorate creation in the atmosphere has not been determined, although it is thought to be a relatively slow process.

Following atmospheric creation, perchlorate returns to the earth's surface dissolved in precipitation. In arid environments, where the rate of deposition exceeds the rate of dissolution by ongoing precipitation, perchlorate can be incorporated into certain geologic formations (Orris, 2004). The widespread presence of microorganisms capable of reducing perchlorate further supports the concept of naturally occurring perchlorate (Coates et al., 1999). Sampling and analysis of geologic materials from both existing collections and new field additions is ongoing by the United States Geological Survey (USGS). Initially, samples were taken in the southwestern United States, but now this sampling effort includes other geographical areas, more diverse terrains, and areas outside the United States. Sampled terrains include playas, calichecontaining soils, dry lakebeds, and evaporite deposits. The USGS is also studying perchlorate in groundwater around the United States to help determine the geographical extent and concentration of perchlorate in the environment; determine which geologic 


\begin{tabular}{|c|c|c|c|c|}
\hline Sample Type & $\begin{array}{l}\text { Number of } \\
\text { Locations }\end{array}$ & $\begin{array}{l}\text { Number of } \\
\text { Samples }\end{array}$ & $\begin{array}{l}\text { Percent with } \\
\text { Perchlorate }\end{array}$ & $\begin{array}{l}\text { Number with } \\
\text { Assoc. Nitrate }\end{array}$ \\
\hline Playas & 28 & 57 & $86^{\mathrm{a}}(96)$ & $>11^{++}$ \\
\hline Soils & 7 & 15 & - & - \\
\hline Soil-caliche & 4 & 10 & 100 & All \\
\hline Soil-nitrate & - & - & - & All \\
\hline Older lakebeds & 3 & 3 & $100^{\mathrm{b}}$ & 2 \\
\hline Nitrate deposits & 3 & 5 & 100 & All \\
\hline Evaporites & 19 & 26 & $27^{\mathrm{a}}$ & Unknown \\
\hline Nonhalite & 9 & 16 & $44^{\mathrm{a}}$ & Unknown ${ }^{d}$ \\
\hline Halite & 10 & 10 & 0 & NA \\
\hline Related $\mathrm{H}_{2} 0$ & 2 & 3 & 100 & Unknown \\
\hline \multicolumn{5}{|c|}{ a High detection limit for some samples. } \\
\hline \multicolumn{5}{|l|}{${ }^{\mathrm{b}}$ All values $<2 \mathrm{ppb}$. } \\
\hline \multicolumn{5}{|c|}{ "Samples other than "pure" halite, commonly mixed salts. } \\
\hline \multicolumn{5}{|c|}{${ }^{\mathrm{d}}$ Early samples not tested for nitrate. } \\
\hline Source: Orris (2004). & & & & \\
\hline
\end{tabular}

Exhibit 1. Perchlorate in natural minerals and materials

materials contain perchlorate; and confirm the rate, concentration, and pervasiveness of perchlorate in precipitation and groundwater. Although USGS studies are ongoing, preliminary analytical results show that perchlorate appears to be naturally present in arid environments (Exhibit 1) and appears to concentrate in a manner similar to nitrate (Walvoord et al., 2003). In addition to these USGS studies, the National Weather Service, in cooperation with the USGS, is conducting analytical testing for perchlorate in precipitation samples collected from weather station evaporation pans. Sampling of the atmosphere at altitude for perchlorate and precursor chemicals may be an additional area for investigation (Orris, 2004).

\section{Chilean Nitrate}

Until recently, naturally occurring perchlorate was known to exist in the environment at only one location - the Atacama Desert in Chile, although similar but less extensive deposits have also recently been found in Peru and Bolivia. The perchlorate in Chile exists in mineralogical association with nitrate of soda caliche deposits that may have been derived in part from past local volcanic activity (Ericksen, 1983; Schumacher 1960).

Chilean nitrate deposits have been mined to produce fertilizer and saltpeter for gunpowder for export since the 1830s (Ericksen, 1981). Chilean nitrate ore has been imported into the United States since at least the late 1800 s for use as fertilizer, as a source of iodine, for saltpeter used in gunpowder, and as a feedstock to make nitric acid, explosives, fireworks, and additional end products. Fertilizer usage currently accounts for the greatest amount of Chilean nitrate imported into the United States. 
Perchlorate was first manufactured in commercial quantities in Masebo, Sweden, in the 1890s by Stockholms Superfostfat Fabrisk AB.

\section{Evaporite Deposits}

Evaporite minerals are those formed through the evaporation of water in arid environments and the subsequent concentration of dissolved solids. Consisting of both marine and nonmarine deposits, they include borates, gypsum and anhydrite, nitrogen compounds, potash, sodium sulfate, sedimentary phosphate, and some other evaporites containing the elements iodine and bromine (Lefond, 1975). Evaporites tend to be deposited in a specific chemical sequence as the concentration increases, such that potassium or other salts that precipitate after halite (rock salt or sodium chloride) are those most likely to contain perchlorate, based on current sample analysis.

In an initial round of USGS testing, more than 90 percent of the natural materials samples had detectable perchlorate, some at low concentrations and others involving potash (sylvite) deposits with perchlorate values up to 489 parts per million (ppm) (Orris, 2004; Orris et al., 2003). Potash is mined and milled in the United States, Canada, and elsewhere. Potash ore has also been recovered via solution mining and exists in solution in the Great Salt Lake in Utah. Economic ore minerals of potash include sylvite, sylvinite, langebinite, kiainite, and carnallite. Most potash production is dedicated to feedstock for making fertilizers. The remaining commercial and industrial uses include potassium-bearing chemicals and reagents, flux in the aluminum industry, as an alternative to deicing salt, water conditioning, detergents, ceramics, and pharmaceuticals. Samples of processed potash products have not tested positive for perchlorate to date.

Other evaporite deposits besides potash may also have the potential of associated perchlorate. Some examples include trona, borax, gypsum, Epsom salts, and others. Borates have been used for boric acid production, as a pesticide/lumber preservative, and as an ointment. Borax is also used as part of an abrasive hand cleaner (Bates, 1969). Colemanite is used as a component for some fertilizers for alfalfa and clover (Lefond, 1975).

\section{Other Potentially Naturally Occurring Perchlorate Sources}

Perchlorate has been detected in seaweed at a concentration of $885 \mathrm{ppm}$ in a sample of kelp collected and analyzed by the USGS (Orris et al., 2003). Whether other types of seaweed or marine algae contain perchlorate has not yet been determined.

\section{Man-made Perchlorate}

Perchlorate was first manufactured in commercial quantities in Masebo, Sweden, in the 1890s by Stockholms Superfostfat Fabrisk AB. Commercial production elsewhere in Europe and the United States followed shortly thereafter. The earliest production in the United States appears to have been by Oldbury Electro-Chemical in Niagara Falls, New York, in 1910. Several perchlorate production plants are known to have operated in the United States since that time (Exhibit 2). In 1960, Schumacher documented over 40 different perchlorate compounds that had been produced in laboratory and industrial settings (Schumacher, 1960). One chemical manufacturer lists 80 perchlorate chemicals in their product line (GFS Chemicals, 2005). However, the vast majority (>99 percent) of manufactured perchlorate compounds consist of the following four: ammonium perchlorate, sodium perchlorate, potassium perchlorate, and perchloric acid. 


\begin{tabular}{|c|c|c|c|}
\hline $\begin{array}{l}\text { Oldbury Electro-Chemical } \\
\text { (later became Hooker } \\
\text { Electrochemical) }\end{array}$ & Niagara Falls, NY & $1910-1940$ & $\begin{array}{l}\text { Hooker Electrochemical was acquired by Occidental Chemical } \\
\text { Company in } 1968\end{array}$ \\
\hline $\begin{array}{l}\text { Western Electrochemical } \\
\text { Company }\end{array}$ & Los Angeles, CA & $1943-1945$ & Manufactured potassium perchlorate \\
\hline $\begin{array}{l}\text { Western Electrochemical } \\
\text { Company }\end{array}$ & Henderson, NV & $1945-2002$ & $\begin{array}{l}\text { Merged with American Potash and Chemical Company in 1955; } \\
\text { acquired by Kerr-McGee in 1967; ammonium perchlorate } \\
\text { manufacture }\end{array}$ \\
\hline Pennsalt Chemicals Corp. & Portland, OR & $1958-1965$ & Currently Elf Atochem North America \\
\hline $\begin{array}{l}\text { Pacific Engineering and } \\
\text { Production Company of } \\
\text { Nevada }\end{array}$ & Henderson, NV & $1958-1988$ & $\begin{array}{l}\text { Ammonium perchlorate plant destroyed by explosion in 1988; } \\
\text { never reopened }\end{array}$ \\
\hline $\begin{array}{l}\text { American Pacific } \\
\text { Corporation }\end{array}$ & Cedar City, UT & 1989-present & $\begin{array}{l}\text { Sole remaining North American producer of ammonium } \\
\text { perchlorate for solid propellant }\end{array}$ \\
\hline Cardox Corporation & Claremore, $\mathrm{OK}$ & Unknown & Closed. Historical operation only. \\
\hline
\end{tabular}

Exhibit 2. U.S. perchlorate manufacturers*

A number of processes have been patented for the production of perchlorates. In general, sodium perchlorate is manufactured electrolytically using sodium chlorate as the feedstock. Potassium perchlorate and ammonium perchlorate are produced in a second step by reacting sodium chlorate as a water solution with other chemicals to create concentrated solutions of either potassium perchlorate or ammonium perchlorate, depending on the added chemical(s). Perchlorate crystals are then precipitated from the solution and are dried to produce a homogeneous dry granular product that is shipped in sacks and drums for sale to manufacturers of various perchlorate-containing end products.

The U.S. Environmental Protection Agency has compiled information on known or suspected users or manufacturers who have shipped more than 500 pounds of perchlorate in any single year (US EPA, 2003). American Pacific Corporation manufactures ammonium perchlorate in Cedar City, Utah, and is currently the sole domestic manufacturer of commercial quantities of propellant-grade ammonium perchlorate. 
Research is being conducted to develop methods for differentiating between naturally occurring and man-made perchlorate in the environment.

\section{Differentiating Natural and Man-made Perchlorate}

Some geographic locations may have a mixture of man-made and naturally occurring perchlorate. The western half of the United States, for example, would appear to represent the most likely area for mixed plumes to occur due to favorable geological and precipitation conditions as well as the proximity of anthropogenic sources.

Research is being conducted to develop methods for differentiating between naturally occurring and man-made perchlorate in the environment. One approach is to use isotopic mass ratio differences: an isotope of oxygen has more mass in naturally occurring perchlorate, while an isotope of chlorine has more mass in man-made perchlorate (Bao \& $\mathrm{Gu}$, 2004). The distribution of the ratio differences can be detected in the laboratory to determine the type of perchlorate. Of course, if the perchlorate of the anthropogenic source was derived from Chilean nitrate, no difference will be able to be determined. In addition, the ability to use isotopic techniques depends highly upon the matrix and concentration of perchlorate present. Solid samples typically require multistep cleanup procedures in order to eliminate the presence of other nonperchlorate oxygen sources, and the concentration of perchlorate in trace-level aqueous samples may be too low for isotopic analysis. Researchers at Louisiana State University and Oak Ridge National Laboratory (ORNL) are on the developmental forefront in this technique (Erickson, 2004).

\section{Uses of Perchlorate and Associated Releases}

Indications are that perchlorate use was limited prior to World War II, with the most prevalent applications being fireworks and railroad signal flares. In 1939, Uses and Applications of Chemicals and Related Materials lists only perchloric acid applications (Gregory, 1939). Volume II of the same document, published in 1944, included additional uses of potassium perchlorate (Gregory, 1944). Potassium perchlorate was placed on the list of strategic chemicals in 1940. In 1960, Schumacher documented over 40 different perchlorate compounds that had been produced in laboratory and industrial settings (Schumacher, 1960). One chemical manufacturer lists 80 perchlorate chemicals in its product line.

Because it is an exceptional oxidizer with additional useful properties, perchlorate is widely used today by industry, the Department of Defense (DOD), the National Aeronautics and Space Administration (NASA), and in a few specific medicinal applications. Perchlorate usage appears to be ubiquitous across the United States, with new information on applications and locations of usage increasing as time passes. In the United States, approximately 90 percent by weight of industrial perchlorate production is dedicated to making ammonium perchlorate for use as an oxidizing agent for solid propellant rockets and missiles. The majority of the remaining U.S. production capacity consists of perchloric acid, sodium and potassium perchlorate, and a variety of other perchlorate salts.

Further background information on perchlorate and its uses may be found in Perchlorate Chemistry, Occurrence, and Remediation: Literature Review (Neumayer et al., 2004) and "Alternative Causes of Wide-Spread, Low Concentration Impacts to Groundwater" (GeoSyntec, 2005).

\section{Solid Propellants}

Of the four main manufactured perchlorate compounds, ammonium perchlorate as used for solid propellant rockets and missiles makes up the largest proportion by volume of U.S. 
production. However, the earliest use of perchlorate as a solid propellant was in the form of potassium perchlorate by the Guggenheim Aeronautical Laboratory at the California Institute of Technology, which developed a formulation that combined asphalt as a binder and fuel with the oxidizer potassium perchlorate for use in jet-assisted take-off units (Hunley, 1999). In the middle-to-late 1940s and early 1950s, perchlorate-based rocket motors that used potassium perchlorate were developed for smaller tactical missiles.

In the early-to-middle 1950s, ammonium perchlorate began replacing potassium perchlorate as the preferred oxidizer for solid propellants in large rocket motors. By 1958, the NIKE Hercules missile, which replaced the NIKE Ajax missile, used a solid propellant motor of polysulfide-ammonium perchlorate. In the 1960s, solid propellant mixtures of ammonium perchlorate and powdered aluminum replaced liquid propellant systems in intercontinental ballistic missile systems. Other examples of solid rocket motors that use ammonium perchlorate include the space shuttle and commercial satellite vehicles. Each of NASA's space shuttle booster rockets contains solid propellant made up of fine aluminum powder fuel and ammonium perchlorate oxidizer along with an organic binder. Many commercial satellite launch vehicles also utilize solid rocket motors with ammonium perchlorate propellant as strap-on boosters to increase payload capacity.

Small rockets attached to ejector seats for pilots, explosive bolts for separating missile stages or other components, and oxygen generators for both civilian and defense aircraft also use perchlorate. Due to degradation issues, many of these devices are replaced as the shelf life expires.

\section{Disposal of Solid Propellants}

Historically, perchlorate-containing debris, scraps of solid propellant and explosives, and rejected rocket motors were disposed of by burning in unlined open burn/open detonation (OB/OD) areas. However, solid propellant or explosives not burned to completion can permit residual perchlorate to be dissolved and cause contamination in soil and ground- and surface waters. The practice is still carried out today, with most propellants being treated in this fashion, although using burn pans to isolate the ground and residue management along with further treatment of the ash, if testing reveals the need. The ash is then drummed for disposal.

An alternative method for solid fuel rockets and missiles also is hydromining or a hog-out process to wash out solid propellant with high-pressure water jets in order to reuse the rocket motor hardware. Unfortunately, in the original system configuration, the liquid waste from the hog-out process was discharged untreated to the ground surface or into leaky lagoons and contaminated ground- and surface water. This historical practice of untreated discharge is no longer employed due to the discovery of associated groundwater plumes. Current practice is to capture and treat the waste stream prior to discharge.

\section{Replacement of Ammonium Perchlorate in Solid Rocket Propellants}

DOD has development programs under way to replace ammonium perchlorate in solid rocket propellants. While alternative energetic oxidizers exist, significant cost, availability, environmental, and performance issues remain that have so far prevented their use in fielded weapon systems and launch vehicles. Each rocket or missile system has unique performance demands that require consideration when attempting to replace ammo-
DOD has development programs under way to replace ammonium perchlorate in solid rocket propellants. 
Within DOD, a backlog of perchlorate-based solid propellant rocket and missiles that have exceeded their perchlorate shelf life are currently in storage. nium perchlorate. The Green Missile Program is a developmental program to demonstrate the viability of replacing ammonium perchlorate in a large rocket or missile system with an environmentally friendly alternative oxidizer.

NASA recently announced a new paraffin-based solid propellant developed and tested to replace perchlorate-based fuels for spacecraft use (NASA, 2003). In testing since 2001, advertised advantages include nontoxicity, carbon dioxide and water combustion products, increased safety due to high stability, and the ability to be shut down and restarted quickly. However, the applicability of this paraffin-based fuel to meet DOD requirements for solid propellants is unknown.

\section{Missile Recycling}

Within DOD, a backlog of perchlorate-based solid propellant rocket and missiles that have exceeded their perchlorate shelf life are currently in storage. These will eventually require treatment or perhaps recycling of the perchlorate. If not treated or recycled, corrosion of these weapon systems will eventually become a concern.

The Army Aviation and Missile Command's Research Development and Engineering Center has developed and demonstrated a missile recycling capability. In this process, the energetic materials processing module uses supercritical anhydrous ammonia in a closed-loop system to recover high-melting-point explosive (HMX), royal demolition explosive (RDX), and ammonium perchlorate for recycling. In 2003 and 2004, 14,600 tactical optical wire-guided (TOW) missiles were processed in this way. Up to 15,000 missiles are projected for recycling in 2005.

\section{Perchlorate Contamination Associated with Solid Fuel Launch Vehicles}

Perchlorate releases to groundwater associated with the space shuttle and other solid fuel launch vehicles at various locations within the NASA sphere of operations have been documented at the Jet Propulsion Laboratory, Cape Canaveral, and elsewhere. At least one study assessing the potential for perchlorate release from launching operations has been published (Lang et al., 2002).

\section{Munitions}

All of the services within DOD have current and/or past weapon systems that contain perchlorate. These weapons systems contain perchlorate in varying amounts. In a 2001 DOD survey of weapons systems containing perchlorate, 259 different munitions and related items such as fuses, flares, illumination rounds, simulators, grenades, and so on, as well as 41 missile systems in the DOD Munitions Items Disposition Action System (MIDAS) database, were listed. For example, current families of munitions containing perchlorate in use by the Army include the following: training simulators, smokes or obscurants, pyrotechnics, grenades, signals and flares, and fuses. Some types of simulators contain relatively high perchlorate concentrations, as do most of those with solid rocket motors.

The Army, Navy, and Air Force are all looking more thoroughly at historical manufacturing records to develop a timeline for perchlorate-containing munitions to better understand the residues that may be on the various training and testing ranges. 
Another DOD program titled "Insensitive Munitions" (IM) involves the selection of materials designed to prevent unplanned explosive reactions, or, in other words, to make munitions safer to handle. Several insensitive munitions high-explosives alternatives being considered for mortar, artillery, and small arms applications are perchloratebased. The safety benefits may outweigh the contamination potential and, if carefully managed, may mitigate the contamination concern.

\section{Munitions Manufacturing}

Historically, at munitions manufacturing facilities, operators washed down equipment used in solid propellant and munitions production with water. These operations present another opportunity for potential releases of perchlorate into the environment.

\section{Munitions Disposal}

In the past, munitions were disposed of in burial pits or destroyed either by burning or exploding in $\mathrm{OB} / \mathrm{OD}$ areas. These methods have the potential to result in releases of perchlorate to the environment; the amounts of perchlorate released can vary greatly, depending on the length of use and the types and amounts of munitions disposed. Historically, burial of unused munitions on ranges has occurred. Over time, corrosion degrades munitions, resulting in the release of incorporated perchlorate into the environment. Therefore, burial sites have contributed to perchlorate contamination on current and formerly used ranges.

$\mathrm{OB} / \mathrm{OD}$ is one approved method for disposal of munitions. However, OB/OD areas cannot ensure the complete consumption of perchlorate in munitions. Nearly all of the OB/OD units and explosive ordnance disposal (EOD) ranges sampled for perchlorate have had detections of perchlorate in groundwater or surface water. Incinerators have been developed that are used to destroy small ordnance items with complete, or very nearly complete, consumption of the perchlorate in munitions.

\section{Perchlorate Replacement Programs}

Efforts are under way to replace perchlorate in at least some munitions. For example, the Army has a preliminary perchlorate replacement program focused on two specific munitions that constitute a large percentage of perchlorate usage. The Edgewood Chemical Biological Center (ECBC) has proposed replacing the photoflash power (the explosive charge inside the pyrotechnic device that contains perchlorates and provides the "bang") with an organic compound to eliminate the use of perchlorate in the two simulators - the M115A2 Artillery Simulator and the M116A1 Hand Grenade Simulator. Alternatively, Picatinny Arsenal has proposed replacing the photoflash powder with a metallic base material. One compound from ECBC and one compound from Picatinny Arsenal will be selected and compared to each other to determine the better one for replacement of these two simulators; however, these two compounds have yet to be chosen. These alternatives will undergo selective testing and comparison to determine best replacement. Other services are also exploring perchlorate replacement.
Incinerators have been developed that are used to destroy small ordnance items with complete, or very nearly complete, consumption of the perchlorate in munitions. 


\begin{tabular}{|c|c|c|c|c|}
\hline Installation & $\begin{array}{l}\text { Military } \\
\text { service }\end{array}$ & State & $\begin{array}{l}\text { Perchlorate concentration } \\
\text { initially detected or } \\
\text { reported }(\mathrm{ppb})\end{array}$ & $\begin{array}{l}\text { Perchlorate cleanup } \\
\text { demonstration } \\
\text { projects under way? }\end{array}$ \\
\hline Edwards Air Force Base & Air Force & CA & 160,000 groundwater (detected 1997) & Yes \\
\hline Holloman Air Force Base & Air Force & NM & 16,000 surface water (detected 1999) & - \\
\hline Aberdeen Proving Ground & Army & MD & 5 drinking water, 24 groundwater (reported 1998) & - \\
\hline Redstone Arsenal & Army & AL & 160,000 groundwater (as of 2003) & Yes \\
\hline White Sands Missile Range & Army & NM & 21,000 groundwater (reported in 1998) & - \\
\hline $\begin{array}{l}\text { Naval Air Weapons } \\
\text { Station, China Lake }\end{array}$ & Navy & CA & 560 groundwater (detected in 2001) & - \\
\hline $\begin{array}{l}\text { Naval Surface Warfare } \\
\text { Center, Indian Head }\end{array}$ & Navy & MD & 1,000 surface water (reported in 1998) & Yes \\
\hline
\end{tabular}

Exhibit 3. Example DOD facilities with known perchlorate contamination*

In addition to individual service-specific programs, DOD's Strategic Environmental Research and Development Program (SERDP) has initiated a new program to investigate perchlorate alternatives.

\section{Perchlorate Contamination at Current and Former Military Facilities}

A number of military facilities have documented perchlorate groundwater and surface water contamination (Exhibit 3). Some defense-related facilities, such as some ammunition and missile/rocket manufacturing facilities, also have known releases. However, in general, it is difficult to ascertain which military bases, depots, formerly used defense sites (FUDS), weapons manufacturing installations, and other defense-related facilities might have perchlorate releases associated with them. The reasons for this are derived from historical uncertainties, the variety of weapons used that contain perchlorate, and temporal use uncertainties. It is also important to note that it should not be assumed that the use of perchlorate-containing weapons systems or perchlorate in general necessarily correlates to a perchlorate release to the environment.

Expended munitions and simulators found in the impact areas can contribute to perchlorate contamination in two ways: (a) munitions containing perchlorate or rocket motors do not function as intended through low-order detonation or (b) function as intended by completely detonating but do not completely consume the propellant or main change and subsequent precipitation leaches perchlorate into the environment. These release mechanisms may contribute a relatively low but long-term mass loading of perchlorate to the environment. The current perchlorate groundwater contamination at the impact areas of the Massachusetts Military Reservation in Cape Cod, Massachusetts, reflects this condition. As more ranges are tested for perchlorate contamination, it seems 
likely that more contamination will be discovered over time. In addition to impact areas, burial areas, OB/OD areas, launching points for rockets and missiles, and missile test stands could also be areas of potential contamination.

\section{Commercial Explosives}

\section{Black Powder}

Black powder is made of a blended mix of saltpeter (potassium or sodium nitrate), charcoal, and sulfur in a 75:15:10 ratio by weight. Nitrate from Chile was used as a source of sodium nitrate in black powder. Chilean nitrate ore, containing naturally occurring perchlorate, was imported into the United States beginning in the 1850s. The sodium nitrate content of the ore made it particularly suitable for use in manufacturing explosives, specifically black powder, replacing more expensive potassium nitrate. Black powder consumption for commercial blasting peaked in 1917 at nearly 300 million pounds, but by 1970 had decreased to 83,000 pounds, used primarily for safety fuses and fireworks (International Society of Explosives Engineers [ISEE], 1980). The historical use of Chilean nitrate containing perchlorate to make black powder presents an unknown in terms of environmental impact.

\section{Black Powder Substitutes}

There are several black powder substitutes on the market that contain perchlorate. The addition of perchlorate is intended to increase velocity and range. These substitutes are mainly ascorbic acid (vitamin C). The use of substitute black powders is becoming increasingly popular, especially with hunters. It is believed that the substitute black powder operations in general are small in terms of overall production, but past practices may have resulted in local perchlorate releases and contamination.

\section{Nitric Acid}

An explosives manufacturing site in Arizona uses Chilean nitrate to manufacture nitric acid as an intermediate for explosives manufacture, including the production of dynamite and other explosive compounds. This process resulted in an otherwise unexpected perchlorate groundwater plume. Although most nitric acid today is made using other chemical processes, Chilean nitrate has been used in the past for its production. Consequently, historical nitric acid manufacturing locations and those facilities that used Chilean nitrate--derived nitric acid may be areas subject to perchlorate contamination.

\section{Modern Commercial Explosives}

A number of modern commercial explosives products may contain sodium perchlorate, ammonium perchlorate, or potassium perchlorate as a chemical sensitizing agent. These products may include emulsions, water gels, delay elements in detonators, and some seismic explosives.

Under some circumstances, an explosives manufacturer may use a chemical sensitizer such as perchlorate to increase the shock-initiation sensitivity of an emulsion or
A number of modern commercial explosives products may contain sodium perchlorate, ammonium perchlorate, or potassium perchlorate as a chemical sensitizing agent. 


\section{Explosive}

Seismic Explosives

Water Gel Products (Bulk \& Packaged)

Continuous Water Gel Explosives (Packaged)

Emulsion Explosives

Electric Detonators

Nonelectric Detonators
Percent Perchlorate

66-72

$0-4$

$0-7$

$0-30$

$0-0.5$

$0-0.89$
Perchlorate Compound

Sodium Perchlorate

Sodium Perchlorate

Sodium Perchlorate

Sodium Perchlorate

Potassium Perchlorate

Potassium Perchlorate

* Source: Institute of Makers of Explosives (IME) (2002).

Exhibit 4. Typical perchlorate-containing explosives and perchlorate content ranges by weight*

water gel product. Emulsion and water gel-type products sensitized using perchlorates are generally designed for specialized applications such as wet/hard/dense rock blasting, in applications to expand drilling patterns or to address excessive rock burdens, in tight underground cuts and tight trenching situations, high precompression conditions, and deep wet trenches and boreholes. In these applications, including certain trenching and utility work, some mine blasting, and specific construction-related blasting activities, perchlorates may be used to preserve product sensitivity where normal sensitizing agents may be conditionally compromised. In these applications, perchlorates have been found particularly effective in maintaining the sensitivity of the explosive.

The amount of perchlorate present in typical perchlorate-containing explosives is quite variable. Examples of perchlorate-containing explosives as derived from Material Safety Data Sheets (MSDSs) are shown in Exhibit 4. Further, some emulsion and water gel explosives may exceed even these concentration ranges.

\section{Perchlorate Contamination Associated with Explosives Manufacturing, Storage, and Use}

At some explosives manufacturing locations, the past practice of using unlined ponds to collect production-derived wastewater may have resulted in releases of perchlorate to groundwater. Explosive solids containing perchlorate also may have accumulated in ponds as sludge. In other instances, wastewaters may have been discharged to surface waters.

Explosives manufacturing has resulted in significant groundwater perchlorate contamination at some locations. In Kansas, for example, a former manufacturer of slurry explosives has contaminated the groundwater as well as surface water ponds. Plants surrounding the ponds have tested positive for perchlorate, as have largemouth bass and channel catfish from the ponds, and local cattle have significant perchlorate plasma as a result of drinking from the ponds. Plumes associated with explosives manufacturing may contain perchlorate as well as explosives and nitrates, the presence of which can make it more difficult to bioremediate using phytoremediation due to selective chemical uptake preferences. Enhanced anaerobic reductive dechlorination may be less hindered under these circumstances. Depending upon the contaminants found in association with perchlorate and the selected remediation technique(s), treatment trains may be complex. 
At other explosives manufacturing facilities, wastes containing perchlorates may have been disposed of at $\mathrm{OB} / \mathrm{OD}$ units with the potential for perchlorate residue generation and subsequent groundwater contamination. Past practices at manufacturing facilities may represent the largest environmental release potential in the commercial explosives industry. Certainly, older explosives-manufacturing facilities that utilized Chilean nitrate as feedstock should be carefully examined due to the presence of perchlorate in historically higher concentrations as well as past management practices.

Soil, surface water, and an associated groundwater plume have also been found at the site of a black powder substitute manufacturer in Kansas. At an adjacent property, sampling conducted by the Kansas Department of Health and Environment (KDHE) has detected perchlorate in agricultural products associated with use of this contaminated water in chicken meat, eggs, milk, beets, and cucumber pickles.

Storage areas used for perchlorate-containing raw materials may have been impacted by perchlorate releases in the past (e.g., historical releases of dust from sacks of perchlorate salts may be a concern at some locations). Landfills may be impacted through the disposal of bags and containers for perchlorate and perchlorate-containing substances. In general, current contemporary raw material storage areas are designed and constructed to prevent or minimize any releases of product. There is little risk of release from complete and packaged explosives in magazines unless carelessness results in packaging puncture with subsequent leakage. However, the potential for release of stored perchlorate salts is dependent upon the construction of the specific storage area (e.g., how well it is isolated from the environment), as well as the management techniques employed with the use of perchlorate.

The use of explosives at blasting sites could cause contamination if there is an incomplete detonation. For example, some rock formations may contain cracks and fissures angling off the main borehole into which an explosive can migrate during the loading process (not all explosives are packaged). The explosive contained in such a fissure could then fail to detonate in the blast. In addition, the potential for residual contamination is increased in the event of a misfire, in which a loaded hole or group of holes in a blasting pattern fails to detonate. Undetonated explosive products remaining after a misfire or incomplete detonation will have more residence time to contact and contaminate groundwater. This scenario is of particular concern where the explosives contain highly soluble perchlorates. Blasting misfires do occur with some variable frequency. Significant effort is made to avoid misfires, primarily because they represent a serious safety hazard. Blast efficiency and cost considerations are secondary concerns. If possible, attempts are usually made to detonate the misfired hole or holes. In some cases, perchlorate contamination associated with blasting may be attributable to pre-blast loss of explosives due to poor housekeeping practices and/or improper spill cleanup.

Groundwater contamination associated with explosives use is suspected at a construction site in Westford, Massachusetts. In a water sample from a pond near the site, Massachusetts Department of Environmental Protection (MADEP; 2005c) officials detected a perchlorate concentration of $819 \mathrm{ppb}$ and detected a perchlorate concentration of $12 \mathrm{ppb}$ in an on-site retention pond. A town water supply well with a detection of 3.3 ppb was shut down, while a private well several hundred feet from the site was sampled, providing a perchlorate concentration of $425 \mathrm{ppb}$. MADEP officials believe the perchlorate contamination is related to explosives used in rock blasting. An examination of the MSDSs by MADEP officials for the emulsion and water gel-type explosives used
The use of explosives at blasting sites could cause contamination if there is an incomplete detonation. 
In some fireworks shells, an oversupply of potassium perchlorate beyond the stoichiometric need is used to suppress the effects of certain chemical elements during reactions. by the sole contractor at these sites showed the explosives contained 20-30 percent perchlorate. According to MADEP, the cause (blasting explosives) and effect (water contamination) relationship at this time appears clear. It should be pointed out that MADEP has taken the lead with respect to state programs by mandating that perchlorate be tested for in all public water supplies in Massachusetts. This requirement led to the initial results into the discovery of this particular perchlorate site.

\section{Fireworks}

In general, fireworks manufacturers encase their chemical compounds in cardboard cylinders or spheres called "shells." The lofting charge or propellant usually consists of black powder, which may also be a component of the explosive charge. When fireworks have a loud concussive bang and a flash of white light, they are termed a "photoflash" or a "flash and sound" effect. This effect is produced using a mixture of potassium perchlorate and fine aluminum or magnesium powder. Common applications include special effects for rock concerts, firecrackers, illumination for night photography, and, of course, fireworks (Conkling, 1990).

Perchlorate or chlorate oxidizers are also typically used because they decompose at high temperatures and release free chlorine. The chlorine is then available to combine with barium, strontium, or copper incorporated as compounds that produce the characteristic green, red, and blue hues respectively (Conkling, 1990). In some fireworks shells, an oversupply of potassium perchlorate beyond the stoichiometric need is used to suppress the effects of certain chemical elements during reactions.

\section{Perchlorate Contamination Associated with Fireworks Manufacture and Use}

Whether fireworks manufacturing facilities have had perchlorate releases during manufacture or storage operations in the United States is unknown and deserves some scrutiny due to the stability of perchlorate in water. It is likely that some of the older sites probably used perchlorate containing Chilean nitrate. Currently, according to the American Pyrotechnics Association, close to 100 percent of fireworks are imported, and in 2003, approximately 221 million pounds of fireworks were sold in the United States. However, some current domestic fireworks production still exists, with several facilities having accidentally exploded over the past 30 years.

Fireworks display designers have been building custom-made shells in the United States for their shows since before the turn of the last century. Some of these may constitute potential sources, at least for those that were using perchlorate in their formulations and some older production that was based on Chilean nitrate.

As mentioned earlier in this article, MADEP is vigorously investigating sources of perchlorate contamination in the state. The investigation has revealed contamination that appears to be from the residue of fireworks displays conducted over time. Fireworksbased perchlorate residue is suspected to have contributed to perchlorate groundwater contamination located in the northwest corner at the Massachusetts Military Reservation (MMR). This area has perchlorate groundwater plumes that emanate from both off- and on-base, with perchlorate concentrations as high as 19 ppb, along with associated explosives such as RDX at up to $7 \mathrm{ppb}$. The groundwater contamination appears to be the result of annual fireworks displays that occurred from 1996 to 2003, as well as 
military pyrotechnics such as smoke pots, smoke grenades, and various perchlorate-containing simulators. Further, perchlorate contamination potentially related to the use of fireworks has been found following water supply well sampling and testing in several other locations around the state.

MADEP is conducting a fireworks residue field test at the University of Massachusetts Dartmouth Campus (MADEP, 2005a). Predisplay analytical results show perchlorate concentrations from nondetect to $36 \mathrm{ppb}$. The site has hosted displays for about 10 years. The amount of perchlorate available for groundwater contamination from fireworks depends upon how many displays, the types of fireworks involved, the amount of misfiring, and the length of time over which displays were conducted in a specified area. Misfires, which may not be managed from an environmental perspective, may contribute significant perchlorate to the environmental loading as well, and their frequency, although relatively low, does vary. Disposal of these misfires may also be of concern if they are drowned in water or treated as solid waste. The question of whether the perchlorate contained in fireworks used for holiday displays, for example, has a significant environmental impact is in need of further research and is likely to be site-specific. Environmental testing such as that being conducted by Massachusetts should be done in other locations where commercial fireworks are commonly used in public displays.

\section{Safety or Hazard Flares}

Perchlorate is one of the primary components found in emergency and signal flares. Flare use is believed to be widespread across the United States. In Santa Clara County, California, for example, more than 40 metric tons of flares were used/burned in 2002 alone (Silva, 2003). Flares containing perchlorate have also been used in aircraft seeding operations in some locations.

In safety or hazard flares, strontium nitrate is combined in a mixture with an oxidizer and a chlorine source (potassium perchlorate), along with various fuels. The available chlorine from the perchlorate and the strontium combine to color the emitted light bright red (Conkling, 1990). Tests indicate that the residue from fully burned flares may still contain a significant amount of perchlorate and that partially burned flares leach even greater concentrations of perchlorate when placed in contact with water (Silva, 2003). Silva points out that fully burned flares can still leach up to almost $2,000 \mu \mathrm{g}$ of perchlorate per flare.

The manufacturing sites of flares are known to have precipitated perchlorate releases into groundwater in, for example, California, and releases are also possible in other locations where similar facilities are or were situated.

\section{Matches}

A safety match uses a blend of potassium chlorate and sulfur with a fuel and binder (Conkling, 1990). Potassium perchlorate is also used in the production of common stick matches. If an environmental concern associated with matches exists, it is likely to be at the production facilities, however. As of 1997, only four American companies produced matches: Lion Corp., Superior Match Co., Atlantis Match Co., and D. D. Bean \& Sons Co. (Retskin, 1997).
Tests indicate that the residue from fully burned flares may still contain a significant amount of perchlorate and that partially burned flares leach even greater concentrations of perchlorate when placed in contact with water 
The applications of the various perchlorate compounds are so varied that it is difficult to characterize the practices or mechanisms that may lead to releases to the environment.

\section{Industrial Uses}

Industrial uses of perchlorate vary widely in scope, as perchlorate is incorporated into or used to make many everyday products, such as airbag initiators for vehicles.

Laboratories also make use of the strong oxidizing and other properties particular to perchlorate. Perchloric acid, for example, is used in some industrial processes, such as in processing rare earth element ores. In Tewksbury, Massachusetts, discharges of perchlorate to a river were found to be associated with a medical device manufacturer's use of perchloric acid (MADEP, 2005b). It is expected that the number of industrial uses will continue to expand as our understanding and awareness of its usage matures. Also, some previous lists of perchlorate uses contained erroneous information.

The applications of the various perchlorate compounds are so varied that it is difficult to characterize the practices or mechanisms that may lead to releases to the environment. This problem is further complicated by the fact that perchlorate compounds may be used in solid or liquid form. The practices at each facility producing, handling, or using perchlorate will have to be examined individually to determine what possibilities exist for releases to the environment to occur.

\section{Laboratories}

Some laboratories in industry, academia, DOD, the Department of Energy (DOE), or in other settings are using or may have used perchlorate compounds or perchloric acid in their research or analytical work. Several examples follow where perchlorate compounds or perchloric acid have been released, or are suspected to have been released, from a laboratory setting (Jet Propulsion Laboratory Fact Sheet, 2004). For example, at Los Alamos National Laboratory (LANL), perchlorate found in groundwater has been associated with past work at the facility (Rickman, 2000). As another example, there has been at least one case of a university chemistry building being temporarily closed due to an accumulation of perchlorate in the ventilation system. As a result, special fume hoods specific to perchloric acid use are now available.

Some detergents may contain perchlorate. For example, detergent-based laboratory glassware cleaning agents such as Alconox, Alcotabs, Liquinox, and NeuTrad have been tested and shown to contain up to $2.5 \mathrm{mg} / \mathrm{kg}$ perchlorate. (Some types of laundry detergent could also potentially contain perchlorate.)

\section{Agricultural Uses}

Some naturally occurring perchlorate is present in products used to enhance agricultural output (e.g., fertilizers). Commonly, nitrates are added to phosphates and potash to produce fertilizers, the ratios of which can be varied to provide for specific plant needs. Potash, a source of soluble potassium essential for plant growth, is mined to produce a fertilizer for agricultural use. The US EPA tested various fertilizers used in the United States and determined that, in general, these fertilizers do not contain perchlorate. This conclusion appears to contradict the USGS findings of perchlorate in some potash samples. Domestic production of potash occurs in Michigan, Utah, and New Mexico. Canada also produces potash, as do some foreign sources. Potash is also used as feedstock in the production of other chemicals 
(Milford, 1999). Other evaporate-derived minerals such as borate are components of certain fertilizers used for plants that need them as trace elements (e.g., alfalfa and clover; Lefond, 1975).

Bulldog Soda, marketed by Sociedad Quimica y Minera de Chile S.A. (SQM) and derived from Chilean nitrate deposits (containing 0.03 percent perchlorate as mined on average), is used as approximately 0.14 percent of the total fertilizer currently applied in the United States. On a historical basis prior to the 1960s, Chilean nitrate-derived fertilizer was the principal fertilizer used in the United States. The US EPA fertilizer study completed in 2001 found that fertilizer derived from Chilean nitrate contained accessory perchlorate in significant concentrations. Subsequently, SQM, the sole mining and processing company of caliche-type deposits, has changed the process for refining the ore, going from $0.5-2 \mathrm{mg} / \mathrm{g}$ to $0.1 \mathrm{mg} / \mathrm{g}$, or 0.01 percent perchlorate. This fertilizer is still applied to a small percentage of cropland in the United States. SQM promotes the use of its products in agriculture for the cotton, tobacco, and citrus sectors. The historical application of higher-concentration perchlorate-containing fertilizer may present a legacy of unknown contamination potential to groundwater, as may the lower-concentration product applied currently (Urbansky et al., 2001).

\section{Medical/Pharmaceutical}

Historically, potassium perchlorate has been used in medical practice for the treatment of thyroid disorders to suppress the overproduction of hormones due to an overactive thyroid gland. Potassium perchlorate is employed in current medical procedures in three different ways. First, it is used in the treatment of induced hypothyroidism or thyrotoxicosis resulting from the primary treatment of tachyarrhythmia or ischemic heart disease by the iodine-containing drug amiodarone. Second, potassium perchlorate is also used to limit the uptake of sodium pertechnetate in the thyroid when the pertechnetate is administered in the course of brain and blood pool imaging and placenta localization. Third, potassium perchlorate has been used as a diagnostic agent in the treatment of certain thyroid disorders. The potassium form of perchlorate appears to be used exclusively for medicinal purposes over other salts of perchlorate, probably due to lessened physiological impacts of the potassium over other possible cations.

The likelihood of medical perchlorate source release to the environment appears to be slight given that amounts stored for medical purposes are small, storage occurs in containers and structures, and hospitals have waste disposal programs.

\section{Water and Wastewater Treatment}

Sodium hypochlorite $(\mathrm{NaOCl})$ is one commonly used method to disinfect water supplies. It is also used to treat pool water, to disinfect groundwater production wells, to treat wastewater in publicly owned treatment works, and in other instances where an effective disinfectant is required. Sodium hypochlorite in solution normally produces some perchlorate ions during the dissociation reactions. This effect is evidenced by the formation of highly unstable and shock-sensitive perchlorate crystals that can form around the rim and cap of long-stored sodium chlorite solutions in laboratories. Thus, the use of sodium hypochlorite has the potential in these applications to introduce detectable perchlorate into the environment. ...potassium perchlorate has been used in medical practice for the treatment of thyroid disorders to suppress the overproduction of hormones due to an overactive thyroid gland. 
...some landfills have received waste perchlorate and perchlorate-contaminated wastes and debris as a matter of course.
Household bleach may also contain perchlorate. According to MADEP, some preliminary testing of household bleach from store shelves shows the presence of perchlorate up to $390 \mu \mathrm{g} / \mathrm{L}$ (equivalent to $\mathrm{ppb}$ ). Chemical age appears to be a factor for perchlorate concentration strength in bleach, as another sampled bottle of bleach left on the shelf for two years tested for perchlorate at 8,000 ppb. Other applications for sodium hypochlorite include its use as a bleaching agent in laundry cleaning; for brightening, oxidizing, deodorizing, and sterilizing in general industry; for decolorizing in textile manufacturing; and for bleaching in the paper and pulp industry. It is also used for skinning of vegetables in the food processing industry.

MADEP has also sampled and tested for perchlorate in the effluent from two separate septic tanks where the influent source water contained approximately 1,000 and $500 \mu \mathrm{g} / \mathrm{L}$ perchlorate. Both effluents were nondetect for perchlorate using liquid chromatography/mass spectrometry/mass spectrometry (LC/MS/MS) analytical technology. It is possible that perchlorate degraded in the anaerobic environment of the septic effluent, although this proposed relationship remains to be proven.

\section{Landfills}

Historically, some landfills have received waste perchlorate and perchlorate-contaminated wastes and debris as a matter of course. Some of these landfills were or are located on-site near a facility using perchlorate, while other landfills were or are located some distance off-site from the facility. It is believed these perchlorate wastes were primarily in the solid form, although whether any perchlorate-containing liquids were also disposed is unknown. Users of perchlorate products who discarded the packaging are also a potential source of perchlorate to landfills due to the perchlorate residue adhering to that packaging. The number of landfills impacted by perchlorate is unknown.

\section{Sodium Chlorate Manufacture and Use}

In the electrolytic cell manufacturing process for sodium chlorate $\left(\mathrm{NaClO}_{3}\right)$, the perchlorate ion is produced as an unintended by-product. In 1999, total U.S. sodium chlorate production capacity was 946,000 short tons per year produced at ten manufacturing sites (Exhibits 5 and 6). An example sodium chlorate MSDS documents a perchlorate content range of 17-22 ppm (17,000-22,000 ppb) (Kerr-McGee Chemical LLC, 2003). Therefore, both the manufacturing process and the use of sodium chlorate are potential sources of perchlorate contamination.

Sodium chlorate is used in agriculture as a nonselective herbicide, mainly on non-cropland for spot treatment of weeds and as a defoliant and for desiccant purposes for crops (Pesticide Management Education Program [PMEP], 1995; Pesticide Action Network North America, 2003). For example, in California, 2,379,994 gross pounds of sodium chlorate were applied at an average rate of 6.05 pounds/acre on a total of 393,143 aces treated in 2002 (Pesticide Action Network North America, 2003). Nonagricultural uses of sodium chlorate include household and industrial bleaching, pulp and paper bleaching, and food processing. Sodium chlorate is also used in numerous applications, as well as as a feedstock to make other chemical products (PMEP, 1995). 


\section{Facility}

CXY Chemicals, USA

Eka Chemicals (Eka-Columbus)

Eka Chemicals (Eka-Washington)

Elf Atochem North America Inc.

Georgia Gulf Corp.

Huron Tech-442 Corp. (Huron Tech 442)

Huron Tech (Huron Tech-Augusta)

Kerr-McGee Chemical LLC

Sterling Pulp Chemicals

Western Electrochemical
Location

Hahnville, LA

Columbus, MS

Moses Lake, WA

Portland, OR

Plaquemine, LA

Perdue Hill, AL

Augusta, GA

Hamilton, MS

Valdosta, GA

Cedar City, UT
Capacity $\left(\times 10^{3}\right.$ short tons/yr)

134

219

63

58

27

40

145

143

110

7

946 total

Source: US EPA (2000)

Exhibit 5. Sodium chlorate production capacity and locations in 1999 in the United States

\begin{tabular}{llcl}
\hline Facility & \multicolumn{3}{c}{$\begin{array}{c}\text { Capacity }\left(\times 10^{3}\right. \\
\text { short tons/yr) }\end{array}$} \\
Elf Atochem & Tacoma, WA & 25 & \multicolumn{1}{c}{ Comments } \\
Georgia-Pacific & Brunswick, GA & 27 & Closed 9/97 $4 / 97$ \\
Huron Tech Corp. & Eastover, SC & 90 & Came online 3/99 \\
Huron Tech 442 Corp. & Perdue Hill, AL & 40 & Scheduled closure mid-2000 \\
Source: US EPA (2000) & & & \\
\hline
\end{tabular}

Exhibit 6. Former sodium chlorate production facilities in the United States and changes as of 1999

It is possible that some current and former sodium chlorate production facilities could also be potential perchlorate sources, as could locations where sodium chlorate is being used for intended purposes.

\section{Uncertain Sources}

The problem when investigating an emerging environmental contaminant is that new information continues to come to light regarding past management practices, current uses, locations of use, or newly suspected but uncertain sources. In the case of the latter, there is a small but apparently growing list of suspected perchlorate sources.

Confirmation and verification testing has not necessarily been done in all cases, and research in these areas is ongoing. A short list of these sources would include cloud-seeding operations, clandestine methamphetamine laboratory wastes, and certain anticorrosion cathodic protections systems. 
The movement of perchlorate in soil is largely a function of the amount of water present.
Cloud-seeding operations have used potassium perchlorate as a component of some of their flare designs to produce nuclei for water-drop formation leading to precipitation. Whether this formulation is still in use is unknown. There is also the possibility that in some clandestine methamphetamine laboratories the process of obtaining red phosphorus from matches and also road flares containing perchlorate may produce a waste stream containing concentrated perchlorates as a by-product.

The results of a Texas Tech University study showed perchlorate being produced at measured rates of $71-77 \mu \mathrm{g} / \mathrm{L}$ by a cathodic protection system in a steel chlorinated water supply storage tank in Levelland, Texas (A. Jackson et al., 2004). The Texas Tech University Water Resources Center is also investigating the potential for the generation of perchlorate by pipelines, buried tanks, and water and oil wells protected by anticorrosion cathodic protection systems in the presence of natural chlorides in soil and groundwater (W. A. Jackson et al., 2003).

\section{Environmental Fate and Transport}

Perchlorate may be released into the environment in the form of a number of different salts, including ammonium perchlorate, potassium perchlorate, sodium perchlorate, and others. All are highly soluble in water, although the relative solubility of the various salts varies. Analytical methods for perchlorate measure the presence of the perchlorate anion in aqueous solution irrespective of the perchlorate salt that was initially introduced into the aqueous system. In certain cases, perchlorate is used in a solution with water as concentrated brine. This liquid form of perchlorate increases the potential as well as the speed of a spill reaching groundwater or surface water. Perchloric acid, which has many industrial uses, is also in a liquid form and thus has the same increased release potential.

The movement of perchlorate in soil is largely a function of the amount of water present. Perchlorate does not bind to soil particles appreciably. Perchlorate salts that are released to the soil in solid form will readily dissolve in whatever moisture is available. If sufficient infiltration occurs, the perchlorate will be completely leached from the soil. Soil moisture containing perchlorate in solution can be taken up by plants through the roots, and several ecological studies have demonstrated the tendency of some plants to concentrate the perchlorate in plant tissues. Some perchlorate may be held in solution in the vadose zone by capillary forces. In arid regions, crystallized perchlorate salts may accumulate at various horizons in the soil due to evaporation of infiltrating rainfall that leached perchlorate from shallower depths.

In dilute concentrations typically found in groundwater, perchlorate behaves conservatively, with the center of mass of the plume moving at the same average velocity as the water. Dispersion results in the contaminant front actually moving faster than the average groundwater velocity. Perchlorate is kinetically very stable under environmental conditions and will not react or degrade in solution under ambient conditions. Biodegradation of perchlorate in groundwater will not occur unless significant levels of organic carbon are present, oxygen and nitrate are depleted, and perchlorate-degrading anaerobic bacteria are present. The combination of high solubility, low sorption, and lack of degradation tends to create plumes that are large, persistent, and difficult to remediate.

When perchlorate is released as a high-concentration brine solution, the movement of the brine in a groundwater system is controlled by density effects (Flowers \& Hunt, 2000). The density contrast between the brine and groundwater may cause the brine to move ver- 
tically, with minimal influence by groundwater movement and little or no dilution. Brine pools may form on top of confining layers, and significant perchlorate mass may move into low-permeability confining layers by diffusion. The brine pools and perchlorate mass absorbed by the confining layers may serve as a long-term source of dissolved contaminant as perchlorate is released to the groundwater by diffusion. This type of release may occur where perchlorates have been manufactured, at rocket motor washout facilities, or other locations where perchlorate has been slurried or handled in concentrated brines.

\section{Site Characterization and Remediation}

Knowing the quantity of perchlorate released at any one time, the number of occurrences, and the time period over which the releases occurred may provide some guidance as to whether to test the soil. Heavy releases of perchlorate, continuous or intermittent over time, should lead to soil testing as well as testing of groundwater/surface water at any point sources, at least to start, especially in dry or desert environments. Surface soil samples may not show any perchlorate, but deeper samples may; thus, both surface and at-depth samples should be taken if soil testing is indicated. In the situation with a dry or desert environment and a deep groundwater table, there can be a precipitation front of perchlorate below the surface but above the groundwater as a caliche layer. If the area has significant precipitation, diffuse source(s), or dispersed source(s), then groundwater and/or adjacent surface water should be tested, as the soil is likely flushed.

Perched aquifers, windows in confining layers, seasonal water-level changes, and potential density currents point to the importance of understanding the groundwater flow regime. Existing groundwater monitoring wells can be taken advantage of, and temporary push-point wells permit investigators to scope the nature and extent of a source rapidly. Since perchlorate acts like nitrate when dissolved in water, perchlorate contamination tends to move with groundwater flow unless stagnant conditions exist. Depending on specific uses, perchlorate may be associated with other contaminants. It is typically associated with nitrates and explosives, solvents, or metals, and more associations may become apparent over time.

\section{CONCLUSION}

Although no federal maximum contaminant level (MCL) for perchlorate in drinking water appears close to being promulgated by the US EPA, two states, California and Massachusetts, are forging ahead on standards development, with issuance projected for prior to the end of 2005. It is expected that other states will follow. With this in mind, the remediation of perchlorate contamination will depend on understanding where and how perchlorate is and was manufactured and used in industry, the Department of Defense, and society in general, that there is the possibility of encountering naturally occurring perchlorate in some arid environments, and that perchlorate could turn up unexpectedly in the course of other remediation projects. Developing a perchlorate knowledge base will enable those responsible for cleanups to know whether perchlorate should be added to their site-specific lists of analytes. The article presented here provides an initial grounding for understanding perchlorate to guide decision making. Those wanting further information are directed to the full ITRC overview document scheduled for publication in the winter of 2005.
Developing a perchlorate knowledge base will enable those responsible for cleanups to know whether perchlorate should be added to their site-specific lists of analytes. 


\section{DISCLAIMER}

The authors comprise the Sources, Uses, and Occurrences Sub-Team of the overall Perchlorate Team of the Interstate Technology and Regulatory Council (ITRC). Any opinions, findings, conclusions, or recommendations expressed in this material are those of the authors and do not necessarily reflect the views of the U.S. government or the respective employing agencies of the authors.

\section{REFERENCES}

Bao, H., \& Gu, B. (2004). Natural perchlorate has a unique oxygen isotope signature. Environmental Science \& Technology, 38, 5073-5077.

Bates, R. L. (1969). Geology of the industrial rocks and minerals. New York: Dover Publications.

Coates, J. D., Michaelidou, U., Bruce, R. A., O'Connor, S. M., Crespi, J. N., \& Achenbach, L. A. (1999). Ubiquity and diversity of dissimilatory (per)chlorate-reducing bacteria. Applied and Environmental Microbiology, 65, 5234-5241.

Conkling, J. A. (1990). Pyrotechnics. Scientific American, 263(1), 96-102.

Dasgupta, P. K., Nartubekabgim, P. J., Jackson, W. A., Anderson, T. A., Tian, K., Tock, R. W., et al. (2005). The origin of naturally occurring perchlorate: The role of atmospheric processes. Environmental Science \& Technology, 39, 1569-1575.

Ericksen, G. E. (1981). Geology and origin of the Chilean nitrate deposits: United States Geological Survey Professional Paper 1188. Washington, DC: USGS.

Ericksen, G. E. (1983). The Chilean nitrate deposits. American Scientist, 71, 366-374.

Erickson, B. E. (2004, November 1). Tracing the origin of perchlorate. Analytical Chemistry, pp. 388A-389A. Retrieved September 27, 2005, from http://www.geol.Isu.edu/News/FacNewsltems/2004BaoPerchlorate.pdf

Flowers, T. C., \& Hunt, J. R. (2000). Long-term release of perchlorate as a potential source of groundwater contamination. In E. Urbansky (Ed.), Perchlorate in the environment (Ch. 14; pp. 177-187). New York: Kluwer/Plenum.

GeoSyntec Consultants. (2005). Alternative causes of wide-spread, low concentration perchlorate impacts to groundwater. Retrieved September 27, 2005, from http://www.dodperchlorateinfo.net/newsroom/ announcements/documents/PerchlorateAlternativeSources.pdf

GFS Chemicals. (2005). Perchlorate compounds. Retrieved September 27, 2005, from http://gfschemicals.com/productcatalog/Perchlorate_Compounds.asp

Government Accountability Office (GAO). (2004). DOD operational ranges-More reliable cleanup cost estimates and a proactive approach to identifying contamination are needed. GAO-04-601. Washington, DC: Author. Retrieved September 27, 2005, from http://www.gao.gov/htext/d04601.html

Gregory, T. C. (1939). Uses and applications of chemicals and related materials, volume I. New York: Reinhold Publishing Corp.

Gregory, T. C. (1944). Uses and applications of chemicals and related materials, volume II. New York: Reinhold Publishing Corp. 
Hunley, J. D. (1999). The history of solid-propellant rocketry: What we do and do not know. Proceedings of the 35th AIAA, ASME, SAE, ASEE Joint Propulsion Conference and Exhibit, Los Angeles, CA, June 20-23. American Institute of Aeronautics and Astronautics, Inc., Reston, VA.

Institute of Makers of Explosives (IME). (2002). Glossary of commercial explosives industry terms. Safety Library Publications (SLP) No. 12. Washington, DC: Author.

International Society of Explosives Engineers (ISEE). (1980). Blaster's handbook (16th ed.). Wilmington, DE: E. I. DuPont de Nemours.

Jackson, A., Arunagiri, S., Tock, R., Anderson, T., \& Rainwater, K. (2004). Technical note: Electrochemical generation of perchlorate in municipal drinking water systems. Journal of the American Water Works Association, 96(7). Retrieved September 27, 2005, from http://www.awwa.org/communications/ journal/2004/july/ExecSummOther/ES5jackson0704.cfm\#TopOfPage

Jackson, W. A., Rainwater, K. A., Anderson, T., Lehman, T. M., Tock, R., Rajagopalan, S., et al. (2003). Distribution and potential sources of perchlorate in the high plains region of Texas: Final report, Phase 1.Water Resources Center, Texas Tech University, Lubbock, TX. Retrieved September 26, 2005, from http://www.waterresources.ttu.edu/final\%20report.pdf

Jet Propulsion Laboratory Fact Sheet. (2004). Cleaning up groundwater beneath JPL. NASA-JPL SSIC No. 9661. Retrieved September 27, 2005, from http://jplwater.nasa.gov/NMOWeb/AdminRecord/Docs/NAS710283C.PDF

Kerr-McGee Chemical LLC. (2003). Sodium chlorate material safety data sheet B-5012. Retrieved September 26, 2005, from http://www.kerr-mcgee.com/siteobjects/files/b5012.pdf

Lang, V. I., Bohman, K. R., Tooley, J., Frolik, S. A., Fournier, E. W., Brady, B. B., et al. (2002). Assessment of perchlorate releases in launch operations II. Aerospace Report No. TR-2003. Los Angeles Air Force Base, California. Retrieved September 27, 2005, from http://ax.losangeles.af.mil/axf/studies/docs/tr200313051.pdf

Lefond, S. J. (1975). Industrial rocks and minerals (4th ed.). Littleton, CO: American Institute of Mining, Metallurgical, and Petroleum Engineers.

Massachusetts Department of Environmental Protection (MADEP). (2005a). Evaluation of perchlorate contamination at a fireworks display Dartmouth, Massachusetts-Draft report. Retrieved September 27, 2005, from http://www.mass.gov/dep/files/clo4/umd-report-0805.htm

Massachusetts Department of Environmental Protection (MADEP). (2005b). Progress report: Merrimack River perchlorate sampling: Summer 2005. Retrieved September 25, 2005, from http://www.mass.gov/dep/files/clo4/merrimack-sampling-summer2005.htm

Massachusetts Department of Environmental Protection (MADEP). (2005c). The occurrence and sources of perchlorate in Massachusetts-Draft report. Retrieved September 26, 2005, from http://www.mass.gov/dep/files/clo4/perchlorate-sources-0805.pdf.

Milford, H. (1999). Extractive non-fuel resources: A look back at mining in New Mexico. In New Mexico's natural resources (Ch. 3). Santa Fe, NM: New Mexico Energy, Minerals and Natural Resources Department. Retrieved September 27, 2005, from http://www.emnrd.state.nm.us/Mining/resrpt/99/3NonFuel.pdf

National Aeronautics and Space Administration (NASA). (2003). NASA tests environmentally friendly rocket fuel. News Release 03-03AR. Washington, DC: Author. Retrieved September 27, 2005, from http://www.nasa.gov/centers/ames/news/releases/2003/03_04AR.html. 
Neumayer, A., Ball, W., Bouwer, E., O'Melia, C., \& Stone, A. (2004). Perchlorate chemistry, occurrence, and remediation: Literature review. The John Hopkins University Department of Geography and Environmental Engineering. Submitted to U.S. Department of Army, Baltimore, MD.

Orris, G. J. (2004, April). Perchlorate in natural minerals and materials. USGS Quarterly Report. Retrieved September 28, 2005, from http://www.itrcweb.org/Documents/Perch_private/USGS_Minerals.doc

Orris, G. J., Harvey, G. J., Tsui, D. T., \& Eldrige, J. E. (2003). Preliminary analyses for perchlorate in selected natural materials and their derivative products. Open-File Report 03-314. U.S. Geological Survey, Washington, DC. Retrieved September 28, 2005, from http://www.itrcweb.org/Documents/ Perch_private/USGS_Occurrence.pdf

Pesticide Action Network (PAN) North America. (2003). California pesticide use-Sodium chlorate. Retrieved September 26, 2005, from http://www.pesticideinfo.org/Detail_ChemUse.jsp?Rec_Id=PC34361

Pesticide Management Education Program (PMEP). (1995). Sodium chlorate-Extension Toxicology Network (EXTONET) pesticide information profile. Ithaca, NY: Cornell University. Retrieved September 26, 2005, from http://pmep.cce.cornell.edu/profiles/extoxnet/pyrethrins-ziram/sodium-chlorate-ext.html

Retskin, B. (1997, July/August). Striking it rich: Match collecting. Cigar Aficionado. Retrieved October 14, 2005, from http://www.cigaraficionado.com/Cigar/CA_Archives/CA_Show_Article/0,2322,540,00.html

Rickman, J. E. (2000). Laboratory detects perchlorate in shallow groundwater. News Release, Los Angeles National Laboratory. Retrieved September 26, 2005, from http://www.lanl.gov/news/releases/archive/00-025.shtml

Schumacher, J. C. (Ed.). (1960). Perchlorates: Their properties, manufacture and uses. American Chemical Society Monograph Series. New York: Reinhold.

Silva, M. A. (2003). Safety flares threaten water quality with perchlorate. San Jose, CA: Santa Clara Valley Water District.

Urbansky, E. T., Collette, T. W., Robarge, W. P., Hall, W. L., Skillen, J. M., \& Kane, P. F. (2001). Survey of fertilizers and related materials for perchlorate $\left(\mathrm{CLO}_{4}{ }^{-}\right)$. EPA/600/R-01/047. Cincinnati, OH: U.S. Environmental Protection Agency, National Risk Management Research Laboratory. Retrieved September 26, 2005, from http://www.epa.gov/ORD/NRMRL/Pubs/600/R01/047.pdf

U.S. Environmental Protection Agency. (2000). Sodium chlorate listing background document for the inorganic chemical listing determination. Washington, DC: Author. Retrieved September 27, 2005, from http://www.epa.gov/epaoswer/hazwaste/id/inorchem/docs/sodchlor.pdf

U.S. Environmental Protection Agency. (2003). List of known perchlorate manufacturers/users. Washington, DC: Author. Retrieved September 25, 2005, from http://www.epa.gov/swerffrr/documents/ knwn_perch_mftrs_usrs_04_03.xls

Walvoord, M. A., Phillips, F. M., Stonestrom, D. A., Evans, R. D., Hartsough, P. C., Newman, B. D., et al. (2003). A reservoir of nitrate beneath desert soils. Science, 302, 1021-1024. 
Clayton W. Trumpolt, P.E., has been an engineer/project manager working on Base Realignment and Closure (BRAC) and active military bases for the Federal Facilities Program, Corrective Action Unit, of the Hazardous Materials and Waste Management Division for the Colorado Department of Public Health and Environment (CDPHE) since 1997. Current projects include the remediation of volatile organic chemicals, nitrates, and heavy metals in groundwater and soils. He has also worked on unexploded ordnance, explosives contamination, and perchlorate. Prior to working at the CDPHE, his experience includes environmental engineering, management, and consulting in both the industrial and regulatory sectors. He also serves as the Sources and Uses Sub-Team Lead for the Perchlorate Team of the Interstate Technology and Regulatory Council (ITRC).

Michael Crain, P.G., is a geologist with the Geoenvironmental and Process Engineering Branch of the U.S. Army Corps of Engineers Hazardous, Toxic, and Radioactive Waste Center of Expertise (HTRW-CX) in Omaha, Nebraska, where he develops technical guidance and provides technical assistance on issues related to hydrogeology, site characterization, environmental monitoring, and groundwater remediation. Prior to joining the HTRW-CX, Mr. Crain worked for 17 years in the Geology Section of the Corps of Engineers Omaha District, including 10 years as section chief. He has project experience in Superfund, Formerly Used Defense Sites (FUDS), Army and Air Force IRP, and BRAC and is a member of the CX team that is developing technical guidance on perchlorate for the FUDS program.

Geoffrey D. Cullison is currently a civilian environmental engineer for Operational Range Sustainability/Environmental Technology/Emerging, Unregulated Contaminants with the Environmental Readiness Division of the Office of Chief of Naval Operations, U.S. Navy in Washington, D.C. A retired Navy Civil Engineer Corps officer, while on active duty, he served in environmental positions related to remediation and other environmental protection efforts from 1982 until 1991. In the Environmental Readiness Division, his duties have been predominantly focused on cleanup policy. He was assigned as the Navy point of contact for perchlorate in 1998 and continues to work perchlorate issues.

Susan J. P. Flanagan, J.D., joined the Institute of Makers of Explosives (IME) in 1997 as Counsel for the Environment, Safety, and Health. In this position, she manages the IME Safety and Health Committee and the Environmental Affairs Committee. She also directs copyright matters as they pertain to the publications of the Institute and is the principal liaison with the US EPA and other federal agencies on matters of interest to the commercial explosives industry.

Lenny Siegel has served as the executive director for the Center for Public Environmental Oversight (CPEO) in Mountain View, California, since 1994, as well as the Pacific Studies Center, a nonprofit public interest information center, since 1970.

Stephen Lathrop, P.E., is a geoenvironmental engineer with Jordan, Jones, and Goulding in Atlanta, Georgia. Mr. Lathrop has eight years' experience as an engineering consultant dealing with environmental remediation projects, with an emphasis on agricultural chemicals, nitrate contamination, and in situ bioremediation utilizing the latest technologies to improve overall project performance. 